\title{
DINAMISASI DAN PRODUKTIVITAS PRIMER SUNGAI CITARUM PROVINSI JAWA BARAT
}

\author{
Anggi Suprabawati*), Arie Hardian, Ekki Al ghifari \\ Jurusan Kimia Universitas Jenderal Achmad Yani \\ *Email: anggi.suprabawati@,lecture.unjani.ac.id
}

\section{ABSTRACT \\ DYNAMISM AND PRIMARY PRODUCTIVITY OF CITARUM RIVER, WEST JAVA PROVINCE}

Monitoring the quality of the river is essentially to know the status of the periodic quality of the river. Good assessment of river water quality should use a combination of physical, chemical and biological parameters. One way that can be done to describe water quality in an area is the primary productivity in the water.Primary productivity is the amount of organic material produced by autotrophic organisms with the help of sunlight. Perifiton as a river microorganism, will provide dissolved oxygen (DO) through photosynthesis to maintain most of the life of the surrounding water, then Periphyton can respond quickly to environmental changes, this is an indicator of changing conditions (Gaiser 2008 and Lakewatch, 2000) in Brown and Wright (2016)Chemical reactions that occur in the aquatic environment also involve interactions between ions and other phases. Some important interactions in the waters are the occurrence of photosynthesis by algae and the exchange of dissolved solids with dissolved gases in water. The same exchange occurs when bacteria degrade organic matter (often in the form of particles) in water. Some important elements move around in aquatic systems as colloidal chemical compounds or are absorbed into soil particles. The equilibrium of physical chemical reactions in waters involves sediment, gas, and water.Sediment is a layer of material or material that covers the bottom of small rivers, lakes, reservoirs, bays, and oceans. Sediments contain fine mixtures and subtle minerals, including clay, silt, and sand, which mix with organic materials. These materials may experience changes in composition from pure mineral ingredients to main organic ingredients. Sediments contain biological ingredients, chemicals, and pollutants in water. This research focuses on converting chemicals from sediments into food chains in water through organisms that deplete important parts of their life cycle, or their dynamics in aquatic sediments.

Keywords: Primary Productivity, citarum river, sediment, water test parameter

\section{PENDAHULUAN}

Sungai dan danau (air permukaan) sering menjadi pusat perhatian, dikarenakan semakin menipisnya persediaan air tanah yang diakibatkan adanya alih fungsi untuk kawasan zona serap di beberapa wilayah di Indonesia. Salah satu daerah aliran sungai (DAS) di Indonesia yang potensinya sangat besar yaitu DAS Citarum masih memiliki banyak kendala diantaranya mempunyai masalah banjir dan penurunan kualitas air. Penurunan kualitas air diduga disebabkan oleh banyaknya permukiman dan industri yang tumbuh di DAS Citarum (Cahyaningsih dan Harsoyo, 2010).

Monitoring kualitas sungai pada hakikatnya adalah untuk mengetahui status mutu sungai dalam periode waktu tertentu. Penilaian kualitas air sungai yang baik hendaknya menggunakan kombinasi parameter fisika, kimia dan biologi. Menurut Wetzel (1983) dalam Telaumbanua dkk. (2013) salah satu cara yang dapat dilakukan untuk menggambarkan ualitas air pada suatu wilayah dapat dilakukan dengan melihat dari produktivitas primer pada perairan tersebut. 
Produktivitas primer adalah jumlah bahan organik yang dihasilkan oleh organisme autotroph dengan bantuan cahaya matahari. Beberapa penelitian mengenai Produktivitas Primer telah banyak dilakukan dengan berbagai macam indikator pengukuran diantaranya dengan menggunakan Fitoplankton sebagai produsen utamanya. Sunarto dkk, (2004), Penelitian telah dilakukan di Teluk Hurun Lampung, dengan metode survai dengan tujuan mengetahui tingkat efisiensi pemanfaatan energi cahaya matahari oleh fitoplankton dalam melakukan produktivitas primer melalui proses fotosintesis. Pengambilan sample dilakukan pada kedalaman $0 \mathrm{~m}$ (pemukaan), $4 \mathrm{~m}, 7 \mathrm{~m}, 11$ $\mathrm{m}$ dan $14 \mathrm{~m}$. Parameter yang diukur adalah produktivitas primer dan intensitas cahaya selama waktu inkubasi. Pengukuran produktivitas primer dilakukan dengan metode oksigen dengan waktu inkubasi 4 . Terlihat ada kecenderungan meningkatnya nilai efisiensi sejalan dengan peningkatan kedalaman.

Irawati dkk, (2009), melakukan penelitian tentang hubungan produktivitas primer fitoplankton dengan ketersediaan unsur hara dan intensitas cahaya di perairan Teluk Kendari. Hubungan produktivitas primer dengan unsur hara dan ICM memperlihatkan keeratan hubungan yang kuat pada ketiga stasiun penelitian sedang produktivitas primer dengan unsur hara dan ICM menunjukkan pola yang hamper sama pada ketiga stasiun penelitian. Pada stasiun luar teluk, unsur hara amonia dan nitrat Bersama ICM menjadi faktor yang memberikan pengaruh nyata terhadap tinggi rendahnya nilai NPP, sedang pada stasiun tengah dan dalam teluk, unsur hara nitrat dan ICM memberikan pengaruh yang nyata terhadap tinggi dan rendahnya nilai NPP di perairan Teluk Kendari.

Heryanto dkk, (2017), melakukan penelitian hubungan Turbiditas dengan Produktivitas Primer dan Nutrient di kawasan pengairan sungai Tohor bagian Timur. Hasil penelitian menunjukkan bahwa turbiditas di perairan berkisar 32,07 - 190 NTU. Konsentrasi nitrat di perairan berdasarkan analisis laboratorium berkisar 2,325 - 2,4291 $\mathrm{mg} / \mathrm{l}$ dan konsentrasi fosfat di perairan berdasarkan analisis laboratorium berkisar $0,0199-0,0796 \mathrm{mg} / \mathrm{l}$. Produktivitas primer di perairan berdasarkan analisis di lokasi penelitian berkisar $-0,4-5 \mathrm{mgC} / \mathrm{m}^{2} /$ hari. Hubungan antara turbiditas dengan produktivitas primer, fitoplankton, nitrat dan fosfat masing-masing menunjukkan hubungan sangat lemah, hubungan sedang, hubungan sedang dan hubungan lemah.

Selain dengan indikator Fitoplankton, Produktivitas Primer dapat dilakukan dengan berbagai macam indikator pengukuran diantaranya dengan menggunakan Perifiton sebagai produsen utamanya.

Barus dkk, (2013), melakukan identifikasi keragaman dan kelimpahan Perifiton di perairan Sungai Deli Sumatera Utara diperoleh keanekaragaman Perifiton terdiri atas 18 genus yang terbagi dalam lima kelas dan didapat indeks keanekaragaman 0,803 - 1,195 ind $/ \mathrm{cm}^{2}$ dimana Sungai Deli tergolong perairan tercemat sedang - berat.

Purwani dkk, (2014), melakukan analisis komunitas Bacillariophyta Perifiton sebagai indicator kualitas air sungai brantas. Pengujian dilakukan menggunakan substrat ubin dan ditemukan sebanyak 34 spesies perifiton. Berdasarkan analisis regresi ganda hubungan $\left(\mathrm{H}^{\prime}\right)$ terhadap faktor fisika-kimia memiliki korelasi, semakin kecil nilai faktor fisika-kimia dan biologi maka nilai $\mathrm{H}^{\prime}$ akan semakin besar begitu juga sebaliknya.

Telaumbanua dkk, (2013), melakukan penelitian Produktivitas Primer Perifiton di Sungai Naborsahan Sumatera Utara dilakukan dengan metode penanaman substrat buatan dari bahan polypropylene yang ditanam diperairan sungai, Substrat buatan dimasukkan kedalam botol BOD dan di inkubasi selama 4 jam di dalam air dan diukur kandungan oksigen terlarutnya dengan menggunakan metode modifikasi Winkler.

Fatmawati dkk, (2016), menganalisis produktivitas primer perifiton di Perairan Air Terjun Tinonggoli Kota Kendari Sulawesi Tenggara. Pemilihan lokasi pengambilan sampel ini dilakukan berdasarkan pertimbangan bahwa daerah hulu merupakan daerah yang memiliki substrat sebagai tempat menempelnya perifiton utamanya pada daerah berbatuan di perairan. Substrat buatan yang di gunakan adalah batu batako yang berukuran 
$5 \times 5 \mathrm{~cm}$ yang sudah dibersihkan terlebih duhulu, lalu diletakkan selama 10 hari setelah peletakkan selama 10 hari, substrat buatan diambil dan di masukan kedalam botol BOD yang berisi air sungai yang masing-masing satu botol inisial (BI), satu botol terang (BT), dan satu botol gelap (BG) yang sudah di saring dengan plankton net agar tidak terdapat fitoplankton dan zooplankton. Hubungan produktivitas primer dengan analisis regresi linear sederhana di mana kecerahan mempunyai hubungan yang lemah terhadap produktivitas primer perifiton sedangkan nitrat dan posfat mempunyai hubungan yang kuat terhadap produktivitas primer.

Perifiton sebagai bioindikator sangat efektif dan ekonomis karena mempunyai beberapa keunggulan dibandingkan dengan organisme lain, antara lain: Perifiton mempunyai distribusi yang luas dengan populasi yang bervariasi, mempunyai peran penting di dalam rantai makanan, siklus hidup pendek, cepat bereproduksi, dijumpai di hampir semua substrat sehingga mampu merekam sejarah habitatnya, banyak dari spesiesnya yang sensitif terhadap perubahan lingkungan sehingga cepat merespon, mampu merefleksikan perubahan-perubahan kualitas air dalam jangka pendek maupun jangka panjang, mudah dalam pengambilan sampel, analisis dan identifikasinya (Soeprobowati dkk, 1999:3) dalam Purwani (2014).

Perifiton menyediakan oksigen terlarut (DO) melalui proses fotosintesis untuk mempertahankan sebagian besar kehidupan air disekitarnya, selanjutnya Perifiton dapat merespon dengan cepat terhadap perubahan lingkungan, ini merupakan indikator perubahan kondisi (Gaiser 2008 dan Lakewatch, 2000) dalam Brown dan Wright (2016)

Berdasarkan latar belakang di atas perlu dilakukan penelitian lebih lanjut mengenai Produktivitas Primer Perifiton serta pengaruh zona Industri di wilayah Bandung Barat yang merupakan salahsatu pemasok limbah cair ke badan sungai di sungai Citarum yang merupakan sumber utama air baku dengan pemanfaatan yang sangat banyak untuk daerah Jawa Barat.

\section{METODOLOGI}

Penelitian ini merupakan penelitian eksperimental sungguhan (True eksperimental) dengan beberapa tahapan kerja yaitu: Menentukan Titik sampling ,Memasang Jaring plankton sebanyak 9 titik sampling, Mengambil sampling air dan sedimen sebanyak 6 (enam) sampel, Preparasi Sampel Pengujian. Pengujian Parameter Lapangan, Pengujian Laboratorium, Pengolahan Data dan Evaluasi

\subsection{Pembuatan Substrat}

Karpet plastik (polypropylene) berukuran $20 \times 10 \mathrm{~cm}$ diletakkan tegak lurus dengan arus sungai pada masing-masing titik pantau. Dilakukan pengamatan sebanyak 3x dalam 21 hari yaitu hari ke-7, ke-14, dan ke21.

\subsection{Produktivitas Primer}

Sampel Perifiton diambil dari substrat dengan cara pengerikan menggunakan kuas. Hasil kerikan (substrat buatan) dimasukkan kedalam botol sampel yang berisi aquabides. (untuk pengamatan keanekaragaman Perifiton dilakukan pengawetan dengan lugol 3-5 tetes). Substrat buatan dimasukkan kedalam 3 botol BOD yaitu botol inisial, botol terang, dan botol gelap yang telah berisi air sungai yang sebelumnya telah disaring menggunakan plankton net. Botol ini langsung diukur kandungan oksigen terlarutnya. Botol terang dan gelap diletakkan didalam air sungai pada kedalaman dimana sampel air diambil untuk di inkubasi selama 4 jam.

Diukur kandungan oksigen terlarut setelah dilakukan inkubasi terhadap botol terang dan botol gelap.

Nilai produktivitas Primer dihitung berdasarkan rumus APHA (2005) yaitu:

$N P P=\frac{B T-B I}{t}$

$\mathrm{NPP}=$ produktivitas primer bersih

$\left(\mathrm{mgO}_{2} / \mathrm{L} / \mathrm{jam}\right)$

$\mathrm{BT}=$ kandungan oksigen terlarut dalam

botol terang $(\mathrm{mg} / \mathrm{L})$

$\mathrm{BI}=$ kandungan oksigen terlarut dalam botol inisial (mg/L)

$\mathrm{t} \quad=$ lama inkubasi (4jam) 
Tabel 1. Acuan yang Digunakan untuk Analisa Air

\begin{tabular}{ll}
\hline Sampling Permukaan & SNI 6989.57:2008 Metode pengambilan contoh air permukaan. \\
\hline Derajat Keasaman (pH) & $\begin{array}{l}\text { Menggunakan Acuan : SNI 06 - 6989.11 - 2004 : Cara uji } \\
\text { derajat keasaman (pH) air dengan menggunakan alat pH meter. }\end{array}$ \\
\hline $\begin{array}{l}\text { Oksigen Terlarut (Dissolved } \\
\text { Oxygen) }\end{array}$ & $\begin{array}{l}\text { Menggunakan Acuan : SNI 06-6989.14-2004 Cara uji oksigen } \\
\text { terlarut secara yodometri (modifikasi azida). }\end{array}$ \\
\hline $\begin{array}{l}\text { Total Suspended Solid (TSS) } \\
\text { Secara Gravimetri }\end{array}$ & $\begin{array}{l}\text { Menggunakan Acuan : APHA 22nd Ed. 2540.D Cara Uji Total } \\
\text { Padatan Tersusupensi (Total Suspended Solid, TSS) Secara } \\
\text { Gravimetri. }\end{array}$ \\
\hline Nitrat (NO3) & $\begin{array}{l}\text { Menggunakan Acuan : Standard Methods for Examination of } \mathrm{Water}^{-} \\
\text {and Waste Water, 22nd,4500.NO } \\
\text { dengan Spektrofotometer Secara Reduksi Kadmium. }\end{array}$
\end{tabular}

Nitrit (NO2)

Menggunakan acuan Acuan : Standard Methods for Examination of Water and Waste Water, 22nd, 4500. $\mathrm{NO}_{2}{ }^{-}-\mathrm{N}, 2005$. Pengujian Nitrit $\left(\mathrm{NO}_{2}^{-}-\mathrm{N}\right)$ dengan Spektrofotometer.

Fosfat $\left(\mathrm{PO}_{4}\right)$ Menggunakan Acuan : APHA 22 ${ }^{\text {nd }}$ Ed. 4500 - P.E. Acid Ascorbic Methode

\section{HASIL DAN PEMBAHASAN}

\subsection{Kondisi Perairan Sungai Citarum}

Penelitian dilaksanakan di DAS Citarum wilayah Bandung Barat dimana titik pemantauan diambil berdasarkan aliran sungai Citarum yang melewati zona Industri di wilayah Bandung Barat.

Titik kordinat Sample Point 1 (SP 1) berada di $6^{0} 56.404^{\prime} S$ dan $107^{0} 32.109^{\prime} E$ yaitu titik pantau setelah melewati zona Industri, sedangkan Sample Point 2 (SP2) pada kordinat $6^{0} 58.305^{\prime} \mathrm{S}$ dan $107^{0} 32.749$ 'Eyaitu titik pantau sebelum memasuki zona Industri wilayah BandungBarat.

Menurut data sekunder terdaftar 7 industri yang membuang ke badan sungai Citarum wilayah Kota Cimahi dan Kabupaten Bandung Barat dengan mayoritas Industri bidang tekstil. Industri tekstil merupakan pemasok zat warna sintesis terbesar saat ini. Pada penggunaannya, zat pewarna ini hanya digunakan sedikit dan sisanya akan dibuang sebagai limbah. Apabila limbah terbuang ke sungai, limbah ini akan menurunkan kualitas air dan akan menimbulkan masalah kesehatan jika air tersebut digunakan oleh masyarakat (Sitanggang, 2017). Maka dari itu dilakukan pemantauan di kedua titik pantau yang mewakili dari pengaruh hasil buangan limbah Industri tersebut.

Sungai Citarum menurut peruntukannya termasuk ke dalam golongan B, C danD, dimana pemanfaatannya sebagai air baku air minum, perikanan, peternakan, perindustrian, dan lain-lain. Oleh karena baku mutu yang berlaku yaitu baku mutu golongan B; C; D (Perda Prov Jabar, 2000).

\subsection{Kelimpahan dan Produktifitas Primer Perifiton}

Produktivitas primer pada dasarnya tergantung pada aktivitas fotosintesis dari organisme autotrof yang mampu mentransformasikan karbondioksida menjadi bahan organik dengan bantuan sinar matahari.

$6 \mathrm{CO}_{2}+12 \mathrm{H}_{2} \mathrm{O} \rightarrow \mathrm{C}_{6} \mathrm{H}_{12} \mathrm{O}_{6}+6 \mathrm{O}_{2}$ 
Tabel. 2. Data Kelimpahan dan Produktifitas Primer Perifiton

\begin{tabular}{|c|c|c|c|c|c|c|}
\hline \multicolumn{7}{|c|}{ Kelimpahan Perifiton } \\
\hline \multirow{2}{*}{ Tanggal } & \multicolumn{2}{|c|}{31 Desember 2017} & \multicolumn{2}{|c|}{7 Januari 2018} & \multicolumn{2}{|c|}{ 14 Januari 2018} \\
\hline & SP 1 & SP 2 & SP 1 & SP 2 & SP 1 & SP 2 \\
\hline $\begin{array}{l}\text { Kelimpahan } \\
\quad \text { (ind/(cm²) }\end{array}$ & 206 & 156 & 633 & 1833 & 1972 & 3483 \\
\hline \multicolumn{7}{|l|}{ Keanekaragaman } \\
\hline \multicolumn{7}{|c|}{$\mathrm{DO}(\mathrm{mg} / \mathrm{L})$} \\
\hline Tanggal & \multicolumn{2}{|c|}{31 Desember 2017} & \multicolumn{2}{|c|}{7 Januari 2018} & \multicolumn{2}{|c|}{ 14 Januari 2018} \\
\hline Pengujian & SP 1 & SP 2 & SP 1 & SP 2 & SP 1 & SP 2 \\
\hline BI & 0,794 & 1,190 & 0,893 & 1,190 & 0,992 & 1,389 \\
\hline BT & 1,091 & 1,587 & 1,389 & 2,976 & 2,579 & 3,968 \\
\hline BG & 0,595 & 0,595 & 0,496 & 0,794 & 0,595 & 0,992 \\
\hline \multicolumn{7}{|c|}{ Produktivitas Primer $\left(\mathrm{mgO}_{2} / \mathrm{L} / \mathrm{jam}\right)$} \\
\hline NPP & 0,074 & 0,099 & 0,124 & 0,447 & 0,397 & 0,645 \\
\hline GPP & 0,124 & 0,248 & 0,223 & 0,546 & 0,496 & 0,744 \\
\hline Respirasi & 0,050 & 0,149 & 0,099 & 0,099 & 0,099 & 0,099 \\
\hline \multicolumn{7}{|c|}{ Kandungan Bahan Organik (mgC/m³/hari) } \\
\hline $\mathrm{C}$ & 1,115 & 1,490 & 1,862 & 6,704 & 5,957 & 9,681 \\
\hline $\begin{array}{l}\text { Penurunan } \\
\text { produktivitas } \\
\text { Primer } \\
\end{array}$ & 25 & & $72 \%$ & & & \\
\hline
\end{tabular}

Lamanya pemantauan selama 21 hari merupakan waktu yang ideal dibutuhkan untuk Perifiton berkembang. Perifiton sebagai bioindikator sangat efektif dan ekonomis karena mempunyai beberapa keunggulan dibanding dengan organisme lain, diantaranya mempunyai distribusi yang luas dengan populasi yang bervariasi, mempunyai peran penting dalam rantai makanan, siklus hidup pendek, cepat bereproduksi, dijumpai disemua substrat sehingga mampu merekam sejarah habitatnya, banyak dari spesiesnya yang sensitive terhadap perubahan lingkungan sehingga cepat merespon (Soeprobowati dkk, 1993 dalam Purwani, 2014)
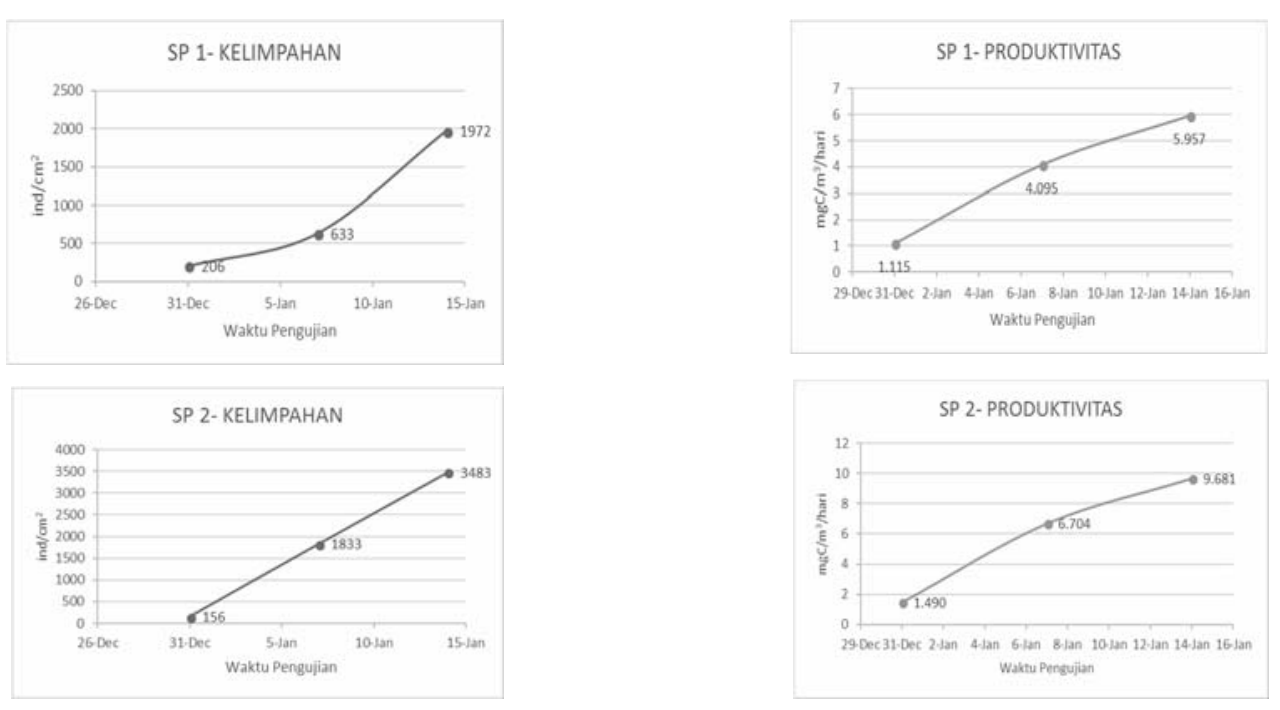

Gambar.1.

Hubungan Antara Kelimpahan dengan Produktivitas Primer 
Kelimpahan perifiton berkisar antara 156-3483 ind $/ \mathrm{cm}^{2}$, dimana kelimpahan perifiton tertinggi berada pada pemantauan minggu ke-3 yaitu tanggal 14 Januari 2018 yaitu 1972 - $3483 \mathrm{ind} / \mathrm{cm}^{2}$ dan produktivitas tertinggi berada pada pemantaun minggu ke-3 dengan nilai 5,957-9,681.

Adanya keterkaitan antara produktivitas primer yang dihasilkan Perifiton dengan kelimpahan dapat terlihat dengan berbanding lurus hasil dari produktivitas dengan kelimpahan.Semakin besar kelimpahan Perifiton di perairan maka semakin besar pula nilai produktivitas primer yang dihasilkan Perifiton.

Dari data yang didapat pada kedua titik pantau terlihat adanya pengaruh zona Industri terhadap produktivitas primer Perifiton. Nilai dari produktivitas primer di SP1 selalu lebih kecil dari nilai produktivitas di SP2. Adanya zona Industri yang membuang limbah ke perairan sungai mempengaruhi produktivitas primer Perifiton tersebut terlihat nyata dengan adanya penurunan nilai produktivitas pada SP1 yang terletah setelah melewati zona Industri.

\subsection{Pengujian Parameter Insitu dan Unsur Hara}

Kelimpahan dan komposisi perifiton diperairan di pengaruhi oleh kualitasair perairan tempat hidupnya. Sehingga aktivitas lingkungan sekitar akan secara langsung atau tidak langsung dapat mempengaruhi kondisi perairan yang dapat mengakibatkan perubahan komposisi dan kelimpahan jenis organisme akuatik seperti perifiton. Pengujian parameter in situ merupakan gambaran awal suatu perairan didalam ekosistem yang fluktuatif baik harian maupun tahunan. Berdasarkan tabel hasil pengujian menunjukan bahwa kualitas sungai Citarum di wilayah Bandung Barat dalam kondisi tercemar berat yang dapat dilihat dari kandungan parameter oksigen terlarut (DO) pada kedua titik pantau berada pada nilai sangat dibawah baku mutu yang sudah ditetapkan dalam Peraturan Daerah Provinsi Jawa Barat No. 39 Th.2000.

Tabel 3. Hasil Pengukuran Parameter Insitu dan Unsur Hara

\begin{tabular}{|c|c|c|c|c|}
\hline $\begin{array}{c}\text { Tanggal } \\
\text { Pengambilan } \\
\text { Sampel }\end{array}$ & Parameter & $\begin{array}{c}\text { SP 1 } \\
\text { (Setelah Zona } \\
\text { Industri) }\end{array}$ & $\begin{array}{c}\text { SP 2 } \\
\text { (Sebelum Zona } \\
\text { Industri) }\end{array}$ & $\begin{array}{c}\text { Baku Mutu } \\
\text { SK.Gub.Jabar } 2000\end{array}$ \\
\hline \multirow{10}{*}{$\begin{array}{c}31 \\
\text { Desember } \\
2017 \\
\text { (Cuaca } \\
\text { Cerah) }\end{array}$} & Laju Alir $(\mathrm{m} / \mathrm{s})$ & 0,7 & 0,7 & - \\
\hline & $\mathrm{pH}$ & 7,10 & 7,40 & $6-9$ \\
\hline & Suhu $\left({ }^{0} \mathrm{C}\right)$ & 29,2 & 29,2 & - \\
\hline & $\mathrm{DO}(\mathrm{mg} / \mathrm{L})$ & 0,794 & 1,230 & $>3$ \\
\hline & $\mathrm{NO}_{2}(\mathrm{mg} / \mathrm{L})$ & $<0,004$ & $<0,004$ & 0,06 \\
\hline & $\mathrm{NO}_{3}(\mathrm{mg} / \mathrm{L})$ & 0,010 & $<0,003$ & 10 \\
\hline & $\mathrm{PO}_{4}(\mathrm{mg} / \mathrm{L})$ & 1,015 & 0,947 & 1 \\
\hline & $\mathrm{TSS}(\mathrm{mg} / \mathrm{L})$ & 63 & 50 & - \\
\hline & Laju Alir $(\mathrm{m} / \mathrm{s})$ & 1 & 1 & - \\
\hline & $\mathrm{pH}$ & 7,05 & 7,17 & $6-9$ \\
\hline & Suhu $\left({ }^{0} \mathrm{C}\right)$ & 24,9 & 24,9 & - \\
\hline 7 Januari & $\mathrm{DO}(\mathrm{mg} / \mathrm{L})$ & 0,893 & 1,190 & $>3$ \\
\hline 2018 (Cuaca & $\mathrm{NO}_{2}(\mathrm{mg} / \mathrm{L})$ & 0,262 & 0,303 & 0,06 \\
\hline \multirow[t]{6}{*}{ Hujan) } & $\mathrm{NO}_{3}(\mathrm{mg} / \mathrm{L})$ & 0,557 & 0,503 & 10 \\
\hline & $\mathrm{PO}_{4}(\mathrm{mg} / \mathrm{L})$ & 2,064 & 0,837 & 1 \\
\hline & $\mathrm{TSS}(\mathrm{mg} / \mathrm{L})$ & 141 & 66 & - \\
\hline & Laju Alir & 1 & 1 & - \\
\hline & $\mathrm{pH}$ & 7,08 & 7,60 & $6-9$ \\
\hline & Suhu $\left({ }^{0} \mathrm{C}\right)$ & 25,2 & 25,4 & - \\
\hline \multirow{5}{*}{$\begin{array}{l}14 \text { Januari } \\
2018 \\
\text { (Cuaca } \\
\text { Cerah) }\end{array}$} & DO (mg/L) & 0,992 & 1,389 & $>3$ \\
\hline & $\mathrm{NO}_{2}(\mathrm{mg} / \mathrm{L})$ & 0,010 & $<0,004$ & 0,06 \\
\hline & $\mathrm{NO}_{3}(\mathrm{mg} / \mathrm{L})$ & 0,047 & 0,013 & 10 \\
\hline & $\mathrm{PO}_{4}(\mathrm{mg} / \mathrm{L})$ & 4,608 & 5,012 & 1 \\
\hline & TSS (mg/L) & 39 & 38 & - \\
\hline
\end{tabular}


Dilihat dari hasil pengujian kandungan DO yang rendah, perairan sungai Citarum wilayah Bandung Barat yang terlewati zona Industri sangat buruk. Hal ini bisa dilihat dengan ketentuan baku mutu yang telah ditetapkan.

Nitrat dan fosfat merupakan unsur penting bagi kehidupan Perifiton di perairan. Effendi (2003) dalam Barus dkk. (2013), menyatakan bahwa nitrat dan fosfat merupakan nutrient utama bagi pertumbuhan tanaman dan alga, sehingga unsur ini menjadi factor pembatas bagi tumbuhan dan alga akuatik serta sangat mempengaruhi tingkat produktivitas perairan. Dapat dilihat pada nilai kelimpahan

SP1 pada tanggal 31 Desember 2017 lebih besar nilainya dibandingkan dengan SP 2,kemungkinan dikarenakan kandungan nitrat $\left(\mathrm{NO}_{3}\right)$ pada SP2 saat itu sangat kecil sehingga pertumbuhan Perifiton mengalami pelambatan.

Berdasarkan indeks keanekaragaman yang didapat dari hasil pemantauan selama 21 hari di sungai Citarum diperoleh nilai 0,37 - 2,02 berada pada $1 \leq \mathrm{H}^{\prime} \leq 3$ menunjukan keanekaragaman sedang, stabilitas komunitas biota sedang dan kualitas air tercemarsedang.

\subsection{Pengaruh Intensitas Cahaya Matahari Terhadap Produktivitas Primer}

Menurut Graham dan Wilcox (2000) dalam Telambanua (2013), peran perifiton di perairan tergenang lebih rendah dari fitoplankton, sedangkan di perairan mengalir, peranan perifiton lebih besar, kecuali perairan yang keruh. Oleh karena itu dilakukan pengukuran TSS sebagai parameter penunjang dalam produktivitas primer yang dihasilkan.

Terjadi lonjakan nilai TSS pada tanggal 7 Januari 2018 di titik pantau setelah melewati zona industri (SP 1) kemungkinan di akibatkan oleh faktor cuaca hujan yang membuat air sungai mengalami turbulensi, dimana sedimen yang ada dipermukaan maupun padatan tersuspensi mengalami kondisi fluktuasi secara cepat. Nilai kecerahan sangat berpengaruh oleh zat-zat terlarut dalam air karena dapat mengurangi banyaknya cahaya yang masuk kedalam air
(Barus ,2004 dalam Barus, 2013). Kecerahan adalah suatu ukuran untuk menentukan daya penetrasi cahaya matahari yang masuk kedalam perairan. Kecerahan suatu perairan menentukan sejauh mana cahaya matahari dapat menembus suatu perairan dan sampai kedalam proses fotosintesis.

\section{SIMPULAN}

1. Dinamisasi Fasa Sungai Citarum diindikasikan dengan nilai kelimpahan perifiton sebelum memasuki zona industri yang berkisar antara $156-3483 \mathrm{ind} / \mathrm{cm}^{2}$ dan setelah memasuki zona industri berkisar antara 206- $1972 \mathrm{ind} / \mathrm{cm}^{2}$ dengan kelimpahan tertinggi pada SP2 pengamatan hari ke21.

2. Zona industri mempengaruhi terhadap penurunan nilai produktivitas primer perifiton di sungai citarum. Dilihat dari data hasil pengukuran produktivitas primer selama 21 hari. Pengukuran mengalami penurunan berkisar 25\% - 39\%

3. Terdapat hubungan antara produktivitas primer perifiton dengan kualitas air dilihat dari unsur hara, yaitu semakin meningkatnya unsur hara di perairan berbanding lurus dengan kenaikan nilai produktivitas primer perifiton. Akan tetapi produktivitas primer juga sangat dipengaruhi oleh nilai TSS dimana nilai TSS akan berbanding terbalik dengan nilai produktivitas primer karena factor cahaya matahari yang tertahan oleh partikel tidak terlarut dalam air.

\section{DAFTAR PUSTAKA}

[APHA] American Public Health Association. 1985. Standard Methods For The Examination of Water and Wastewater. United Book Press Inc,Maryland.

[APHA] American Public Health Association. 2005. Standard Methods For The Examination of Water and Wastewater. United Book Press Inc,Maryland. 
[APHA] American Public Health Association. 2012. 22nd Ed. 2540.D Cara Uji Total Padatan Tersusupensi (Total Suspended Solid, TSS) Secara Gravimetri

[APHA] American Public Health Association $22^{\text {nd }}$ Ed. 4500 - P.E. Acid Ascorbic Methode.

Barus, S.A, Yunasfi, dan Suryanti,A. 2013. Keanekaragaman dan Kelimpahan Perifiton di Perairan Sungai Deli Sumatera Utara. Sumatera Utara:Fakultas Pertanian Universitas SumateraUtara

Brown, P dan Wright, A, L. 2016. The Role of Periphyton in the Everglades. Florida: Soil and Water Science Department University of Florida IFAS Extension.

Cahyaningsih, A dan Harsoyo,B. 2010.Distribusi Spasial Tingkat Pencemaran Air di Das Citarum. Jurnal Sains \& Teknologi Modifikasi Cuaca. 11 (2), 2010: 1-9

Fatmawati. 2016. Produktivitas Primer Perifiton Di Perairan Air Terjun Tinonggoli (Nanga-Nanga) Kota Kendari Sulawesi Tenggara. Kendari: Fakultas Perikanan dan Ilmu Kelautan Universitas Halu Oleo.

Heryanto,S.2017.Hubungan Turbiditas Dengan Produktivitas Primer dan Nutrien di Kawasan Perairan Desa Sungaitohor Bagian Timur, Kecamatan Tebingtinggi Timur, Kabupaten Kepulauan Meranti, Provinsi Riau. Pekanbaru:Fakultas Perikanan dan Kelautan Universitas Riau.

Irawati, N. 2013. Hubungan Produktivitas Primer Fitoplankton Dengan Ketersediaan Unsur Hara Dan Intensitas Cahaya Di Perairan Teluk Kendari Sulawesi Tenggara. Jurnal Biologi Tropis. 13(2).

Manahan,Stanley

E."ENVIRONMENTALSCIENCE,TEC HNOLOGY,ANDCHEMISTRY"
Environmental Chemistry. Boca Raton: CRC Press LLC, 2000

Marganingrum,D,Roosmini,D,Pradono,dan Sabar,A.2013.Diferensiasi Sumber Pencemar Sungai Menggunakan Pendekatan Metode Indeks Pencemaran (IP) (Studi Kasus: Hulu DAS Citarum). Ris.Geo.Tam Vol. 23, No.1, Juni 2013(41-52).

Menteri Negara Lingkungan Hidup. 2007. Pedoman Pengkajian Teknis Untuk Menetapkan Kelas Air. Jakarta, Indonesia.

Purwani, A, Surwono, H, dan Prabaningtyas, S. 2014. Analisis Komunitas Bacillariophyta PerifitonSebagai Indikator Kualitas Air Di Sungai Brantas Malang, Jawa Timur. Malang: Universitas Negeri Malang

Rukminasari, N, Nadiarti, dan Awaludin, K. 2014. Pengaruh Derajat Keasaman Air Laut Terhadap Konsentrasi Kalsium dan Laju Pertumbuhan HALIMEDA $S P$. Jurnal Ilmu Kelautan dan Perikanan Vol 24, No 1, April 2014.

Simbolon,Camelina,Mulya,B.M,dan Desrita. 2015. Keanekaragaman Perifiton di Sungai Belawan Kecamatan Pancur Batu Kabupaten Deli Serdang Provinsi Sumatera Utara.

Sitanggang, P.Y., 2017. Pengolahan Limbah Tekstil dan Batik di Indonesia.Bandung Institute of Technology.

Standard Methods for Examination of Water and Waste Water, 22nd, 4500. $\mathrm{NO}_{2}^{-}-\mathrm{N}$, 2005. Pegujian Nitrit $\left(\mathrm{NO}_{2}^{-}-\mathrm{N}\right)$ dengan Spektrofotometer.

Standard Methods for Examination of Water and Waste Water, 22nd, 4500. $\mathrm{NO}_{3}^{-}-\mathrm{N}$, 2012. Pegujian Nitrat $\left(\mathrm{NO}_{3}{ }^{-}-\mathrm{N}\right)$ dengan Spektrofotometer Secara Reduksi Kadmium.

[SNI] Standar Nasional Indonesia 06 6989.11 - 2004 .Cara uji derajat keasaman (pH) air dengan menggunakan alat $\mathrm{pH}$ meter 
[SNI] Standar Nasioal Indonesia 06-6989.142004 Air dan air limbah -Bagian14: Cara uji oksigen terlarut secara yodometri (modifikasi azida)

[SNI] Standar Nasional Indonesia 6989.57:2008 Metode pengambilan contoh air permukaan

Sunarto, A, Sri., dan Hamdani, H. 2004. Efisiensi Pemanfaatan Energi Cahaya Matahari Oleh Fitoplankton dalam Proses Fotosintesis. Jurnal Akuatika. 2 (2).

Telaumbanua, B,V. 2013. Produktivitas Primer Perifiton di Sungai Naborsahan Sumatera Utara. Sumatera Utara: Universitas Sumatera Utara.
Warlina, L. 2004. Pencemaran Air: Sumber, Dampak dan Penanggulangannya. Bogor: Institut Pertanian Bogor

Widdyastuti, R. 2010. Produktivitas Primer Perifiton di Sungai Ciampea, Desa Ciampea Udik, Bogor Pada Musim Kemarau 2010. Bogor: Fakultas Perikanan dan Ilmu Kelautan Institut Pertanian Bogor

Yunianto, B. 2009. Kajian Pemanfaatan Ruang Kawasan Karst Citatah Rajamandala Untuk Pertambangan Dan Industri Pengolahan Kapur Di Kabupaten Bandung Barat, Jawa Barat. Bandung: Pusat Penelitian dan Pengembangan Teknologi Mineral dan Batubara. 